\title{
Yellowish dots in the retina: a finding of ocular syphilis?
}

\section{Pontos amarelados na retina: um achado da sífilis ocular?}

\author{
Renan Albert Mendonça Rodrigues ${ }^{1}$, Heloisa Moraes do Nascimento², Cristina Muccioli ${ }^{1}$
}

\begin{abstract}
Here we report the occurrence of pale yellowish perivascular preretinal dots in 12 patients with ocular syphilis. A case series of these patients was examined between March and October 2012 at the Uveitis Sector of Universidade Federal de São Paulo. After diagnostic confirmation of syphilis, fundus photographs and optical coherence tomography (OCT) were performed to verify the localization of the dots, and patients were treated with IV crystalline penicillin for 14 days. The study comprised 11 men (91.6\%), 19 eyes, median presentation age of 38.1 years, and panuveitis as the main clinical manifestation (seven patients, 58.3\%), being bilateral in four. Ten patients were taking oral prednisone (83.3\%). Serum panels performed by the Venereal Disease Research Laboratory (VDRL) showed positive results in eight patients (66.7\%), whereas VDRL cerebrospinal fluid (CSF) tests were negative in seven of nine collected (77.8\%). However, serum FTA-Abs was positive in $100 \%$ of patients, and eight patients $(66.7 \%)$ had HIV infection. The best corrected visual acuity (BCVA) presented after treatment improved in 10 eyes (55.6\%), did not change in seven eyes (38.9\%), and worsened in one eye (5.6\%). Although not yet acknowledged in the literature as a typical manifestation of ocular syphilis, these are very common findings in clinical practice. We believe that preretinal dots are due to perivasculitis secondary to treponema infection. It is important recognize them and remember that syphilis can present in several forms, including the one presented in this study.
\end{abstract}

Keywords: Syphilis; Uveitis; Panuveitis; Uveitis, posterior/diagnosis; Retina; Tomography, optical coherence; Eye infections, Bacterial; Case reports

\section{RESUMO}

Relatar a ocorrência de pontos amarelo-esbranquiçados perivasculares pré-retinianos em 12 pacientes com sífilis ocular. Série de casos de 12 pacientes examinados entre março e outubro de 2012 no setor de uveítes da UNIFESP.Após confirmação diagnóstica de sífilis ocular, retinografias e OCT (optical coherence tomography) foram realizados para verificar a localização dos pontos e os pacientes foram tratados com penicilina cristalina IV por 14 dias. Dados demográficos incluíram 11 homens (91,6\%), 19 olhos, mediana de idade de 38,1 anos, e a manifestação clínica principal foi panuveíte (7 pacientes, 58,3\%), sendo bilateral em 4. Dez fizeram uso de prednisona oral (83,3\%). VDRL (Venereal Disease Research Laboratory) sanguíneo foi positivo em 8 pacientes (66.7\%), VDRL no líquor foi negativo em 7 de 9 coletados (77,8\%), FTA-Abs sanguíneo foi positivo em $100 \%$ e 8 pacientes $(66,7 \%)$ eram HIV positivos, AV após tratamento melhorou em 10 olhos (55,6\%), não se alterou em 7 (38,9\%) e piorou em 1 olho (5,6\%). Embora ainda não reconhecida na literatura como uma manifestação típica da sífilis ocular, este achado é muito comum na prática clínica. Acreditamos que esses pontos são devidos a perivasculite secundária à infecção pelo treponema. É importante os reconhecer elembrar que a sifilis pode se apresentar de várias formas, incluindo essa apresentada aqui.

Descritores: Sífilis; Uveíte; Panuveíte; Uveíteposterior/diagnóstico; Retina; Tomografia de coerência óptica; Infecções oculares bacterianas; Relatos de casos

\section{INTRODUCTION}

Syphilis is a sexually transmitted disease. Ocular infection can manifest in secondary or tertiary syphilis, and is considered the great "mimicker" of infectious and noninfectious forms of uveitis (1). Uveitis is the most common ocular manifestation, occurring in 2.5\% to $5.0 \%$ of cases of secondary or tertiary syphilis. The most common clinical form is acute bilateral multifocal chorioretinitis, with whitish-yellow subretinal plaque. In addition, it can present with panuveitis and vitreitis ${ }^{(2)}$. In the posterior segment, several signs were described in both HIV infected and noninfected patients, including vitreitis, focal retinitis, papillitis, serous retinal detachment, and neuroretinitis, among others. In HIV-infected patients, yellowish-white placoid lesions can be observed in the macula or juxtapapilar, and these are usually flat and with an atrophic center. A dense vitreitis can be the only sign of syphilitic uveitis in HIV-infected patients ${ }^{(3)}$.

The treatment of choice is IV crystalline penicillin ${ }^{(4)}$. Allergic patients can be treated with doxycycline or erythromycin; however, nonpenicillin treatment generally is less effective ${ }^{(5)}$. Although, desen- sitization is also a choice, it would usually take very long to take effect, given the need for urgent therapy in potentially sight-threatening syphilitic uveitis.

In this case series, we present preretinal pale yellowish dots ( $\mathrm{Fi}$ gures 1 and 2) as a manifestation of syphilitic uveitis, and we consider this finding a typical and specific manifestation of ocular syphilis.

\section{CASE REPORT}

This case series was performed between March and October 2012 at the Uveitis Sector of Universidade Federal de São Paulo (UNIFESP) on 12 patients who presented with pale yellowish preretinal dots.

Confirmation of ocular syphilis was based on clinical manifestations, and all patients were submitted to both Venereal Disease Research Laboratory (VDRL) and FTA-Abs for syphilis. In addition, lumbar puncture was performed. After diagnostic confirmation of syphilis, fundus photographs and optical coherence of tomography (OCT) (Figure 3) were performed to identify the localization of dots.
Submitted for publication: June 30,2014

Accepted for publication: August 5, 2014

Study conducted at Department of Ophthalmology, Universidade Federal de São Paulo (UNIFESP).

Department of Ophthalmology and Visual Sciences, Universidade Federal de São Paulo (UNIFESP), São Paulo, SP, Brazil.

Uveitis Sector, Department of Ophthalmology and Visual Sciences, Universidade Federal de São Paulo (UNIFESP), São Paulo, SP, Brazil.
Funding: No specific financial support was available for this study.

Disclosure of potential conflicts of interest: None of the authors have any potential conflicts of interest to disclose.

Corresponding author: Renan Albert Mendonça Rodrigues. Rua Botucatu, 821 - São Paulo, SP 04023-062 - Brazil - Email: renanrodrigues.med@gmail.com

Study approved by the Ethics Committee of the Universidade Federal de São Paulo - UNIFESP/EPM. Project number: 180.546 . 


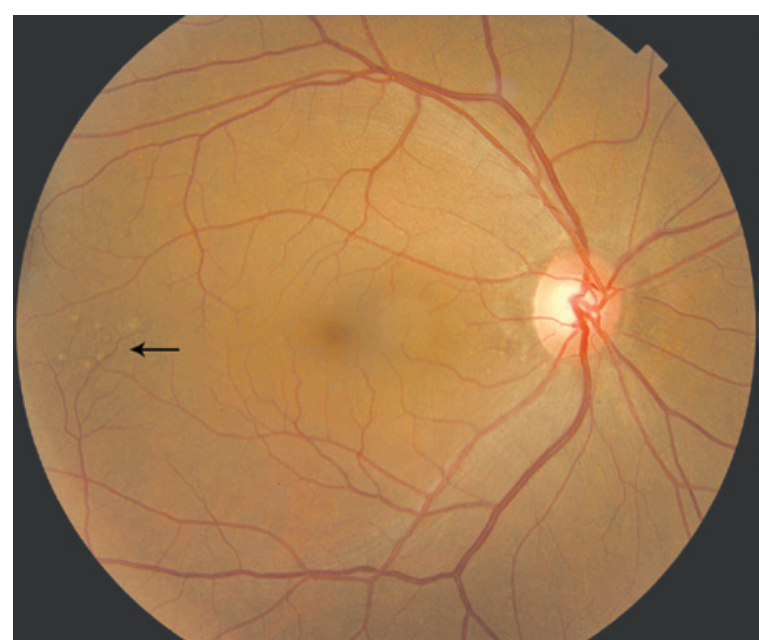

Figure 1. Pale yellowish perivascular retinal dots at the end of the inferior temporal arcade (arrow); same dots were viewed at the periphery.

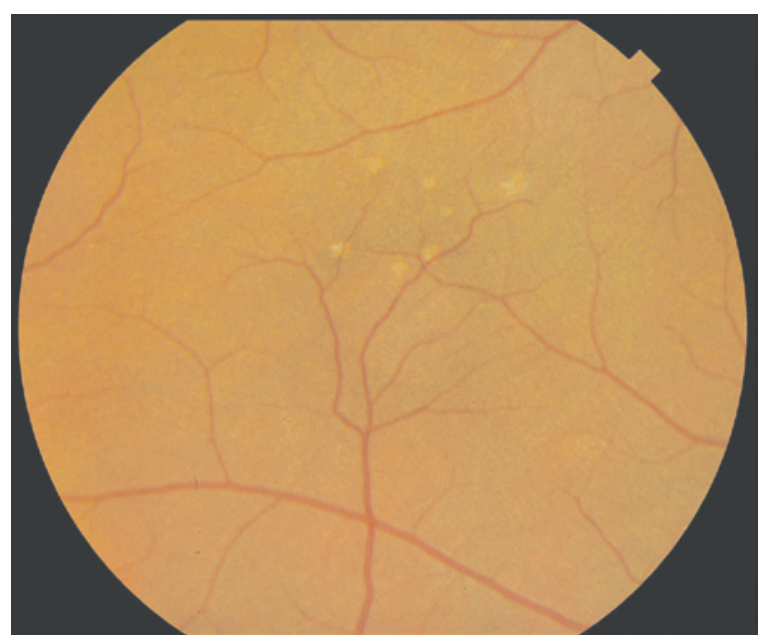

Figure 2. Detail of the pale yellowish perivascular retinal dots.

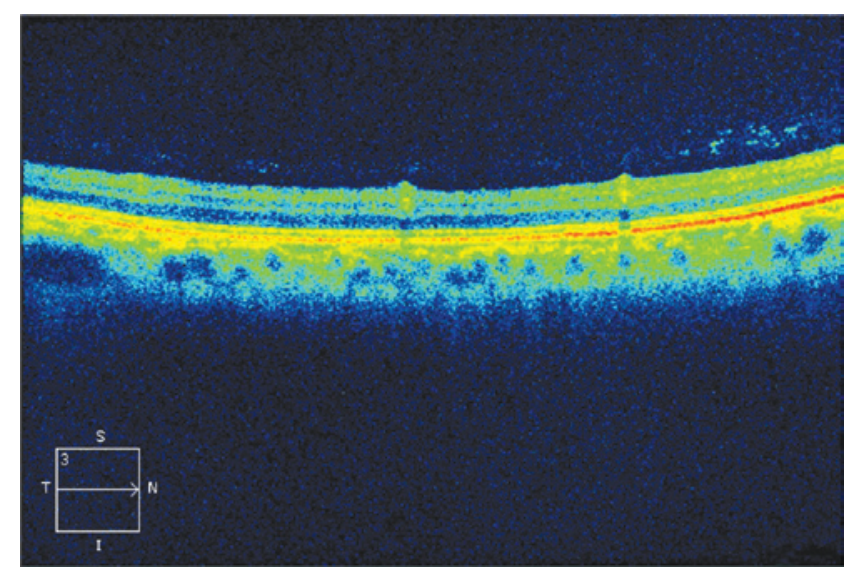

Figure 3. Optical coherence tomography (OCT) of the region, showing perivascular inflammation, with local vitreitis.
All cases were treated with IV crystalline penicillin (20 million units/day) for 14 days, which was very effective in controlling the disease.

Pale yellowish dots were mainly overlying vasculature and also in periphery. OCT was performed and indicated location in the vitreous-retina transition.

In our 12 cases, 19 eyes were affected, 11 patients were men (91.6\%), the median presentation age was 38.1 years, and panuveitis was the main clinical manifestation. Four patients presented bilateral panuveitis (33.3\%), three presented unilateral panuveitis (25.0\%), two presented bilateral posterior uveitis (16.7\%), one presented unilateral retinitis (8.3\%), one presented bilateral optic neuritis (8.3\%), and one presented anterior uveitis (8.3\%). Ten patients were taking oral prednisone (83.3\%). Serum VDRL was positive in eight patients (66.7\%), cerebrospinal fluid (CSF) VDRL was negative in seven of nine collected $(77.8 \%)$, serum FTA-Abs was positive in $100 \%$ of patients, and eight patients (66.7\%) had HIV infection. The best corrected visual acuity (BCVA) after treatment improved in 10 eyes (55.6\%), did not change in seven (38.9\%), and worsened in one (5.6\%). Table 1 shows demographic, clinical, and laboratory findings of all patients.

\section{DISCUSSION}

Ocular syphilis is a common manifestation of secondary or tertiary syphilis and constitutes an important factor in diagnosis and treatment of different stages of syphilitic infection. Although very common in clinical practice, syphilis infection is under reported in Brazil. According to the Brazilian notification system (DATASUS), prevalence of syphilis during pregnancy was $1.6 \%$ in 2004 , with an estimate of 48,425 cases. From 2005 to $2012,57,700$ cases of syphilis during pregnancy were notified, with an incidence rate of 0.6 in 1,000 births in 2005, reaching 5 in 1,000 births in 2012. Most were detected in women between 20 and 29 years, and of those diagnosed in 2011 , only $11.5 \%$ had their partners treated. These data show increases in both notification and incidence of the disease in the past few years in Brazi( ${ }^{(6)}$.

Fu et al. ${ }^{(7)}$ described a series of nine eyes from eight patients with syphilitic retinitis, who presented creamy yellowish superficial, multifocal, retinal precipitates, overlying an area of retinitis. Most eyes (66.7\%) presented a single group of precipitates, while others (33.7\%) presented a multiple group of precipitates associated with distinct areas of retinitis. All manifestations resolved between 2 and 3 weeks after initiation of the treatment ${ }^{(7)}$.

Yang et al. ${ }^{\left({ }^{(8)}\right.}$ described a Chinese patient who presented mutton fat precipitates in the posterior vitreous membrane with retinal vasculitis in both eyes. In addition, Yang and colleagues described three other eyes in two patients, which presented multiple perimacular whitish dots termed as "multiple punctiform retinian precipitates", very similar to those found in our cases. Our study, as suggested by these authors, indicates that these precipitates or pale yellowish dots are highly suggestive of ocular syphilis. Yang et al. ${ }^{(8)}$ presumed that they were provenient from treponema collections and inflammatory cells, both pre- and intraretinal.

Reddy described a HIV patient with "multiple preretinal aggregates" resting on a sectorial area of detached retina that had a diffuse yellowish-white ground glass full-thickness opacification ${ }^{(9)}$. Furthermore, clinical and OCT presentation were similar to our findings and resolved after initiating treatment for syphilitic retinitis.

Fundus photographs showed that these dots were overlying vasculature and also located at the periphery. OCT revealed that they were located in the vitreous-retina transition (Figure 3), probably due to local perivasculitis, which is typical in treponema infection, as the local vitreitis also suggests. After treatment, ocular findings disappeared in all patients but one, a 55-year-old, female without HIV infection; even with resolution of ocular symptoms, the findings remained present 4 months after treatment with crystalline penicillin.

Although not yet acknowledged in the literature as a typical sign, these are very common findings in ocular syphilis. Other authors 
Table 1. Demographic, clinical, and laboratory data of the patients

\begin{tabular}{|c|c|c|c|c|c|c|c|c|c|c|}
\hline Patient & Sex & Age & Uveitis & Oral prednisone & Liquor VDRL & Serum VDRL & Serum FTA-Abs & Inicial BCVA & Final BCVA & HIV \\
\hline \multirow[t]{2}{*}{1} & M & 30 & Bilateral panuveitis & Yes & Positive & + & + & $\mathrm{HM}$ & $\mathrm{HM}$ & Yes \\
\hline & & & & & & & & $20 / 60$ & $20 / 40$ & \\
\hline 2 & M & 43 & Unilateral retinitis & Yes & Not collected & + & + & $20 / 40$ & $20 / 20$ & Yes \\
\hline \multirow[t]{2}{*}{3} & M & 49 & Bilateral panuveitis & Yes & Negative & + & + & LP & $H M$ & Yes \\
\hline & & & & & & & & HM & $20 / 150$ & \\
\hline \multirow[t]{2}{*}{4} & M & 40 & Bilateral panuveitis & Yes & Negative & - & + & CF1 m & $20 / 60$ & No \\
\hline & & & & & & & & $20 / 60$ & $20 / 25$ & \\
\hline 5 & M & 40 & Unilateral panuveitis & Yes & Negative & + & + & CF1 m & CF1 m & Yes \\
\hline 6 & M & 37 & Unilateral panuveitis & No & Negative & + & + & $H M$ & CF $50 \mathrm{~cm}$ & Yes \\
\hline \multirow[t]{2}{*}{7} & M & 32 & Bilateral panuveitis & Yes & Not collected & - & + & CF $2 \mathrm{~m}$ & $L P$ & No \\
\hline & & & & & & & & $20 / 100$ & $20 / 20$ & \\
\hline 8 & M & 36 & Unilateral panuveitis & Yes & Negative & - & + & CF $2 \mathrm{~m}$ & $20 / 25$ & Yes \\
\hline 9 & M & 28 & Anterior uveitis & Yes & Not collected & + & + & $20 / 25$ & $20 / 25$ & Yes \\
\hline \multirow[t]{2}{*}{10} & M & 28 & Bilateral optic neuritis & Yes & Positive & + & + & $20 / 20$ & $20 / 20$ & Yes \\
\hline & & & & & & & & $20 / 40$ & $20 / 20$ & \\
\hline \multirow[t]{2}{*}{11} & $\mathrm{~F}$ & 55 & Bilateral & No & Negative & + & + & $20 / 20$ & $20 / 20$ & No \\
\hline & & & Posterior uveitis & & & & & & & \\
\hline \multirow[t]{2}{*}{12} & M & 40 & Bilateral & Yes & Negative & - & + & CF $1 \mathrm{~m}$ & CF $1 \mathrm{~m}$ & No \\
\hline & & & Posterior uveitis & & & & & $20 / 60$ & $20 / 60$ & \\
\hline
\end{tabular}

suggest that they can be granulomas, but more studies, particularly pathologic studies, are required. It is important to acknowledge these findings because syphilis can present in several forms. In conclusion, ophthalmologists should always consider syphilis in the differential diagnosis of uveitis, particularly in the presence of preretinal dots, which appear to be very suggestive of ocular syphilis.

\section{ACKNOWLEDGMENTS}

We thank Gustavo Salomão and Maíra de França for contribution in screening and referral of ocular syphilis cases.

\section{REFERENCES}

1. Karunaratne I, Sharma S, Dick A, Carrington D, Horner P. Shared care approach to managing ophthalmological disease in patients with positive treponemal serology: a case series. Int J STD AIDS. 2012;23(4):291-6.
2. Julie H. Tsai, Jennifer R. Chao, Narsing A. Rao: Syphilitic and Other Spirochetal Uveitis in Yanoff M, Duker JS. Ophthalmology. $3^{\text {th }}$ ed. Elsevier; 2009 p.798-802.

3. Amaratunge BC, Camuglia JE, Hall AJ. Syphilitic uveitis: a review of clinical manifestations and treatment outcomes of syphilitic uveitis in human immunodeficiency virus-positive and negative patients. Clin Exp Ophthalmol. 2010;38(1):68-74.

4. Ghanem KG, Kimberty AW. Management of adult syphilis. Clin Infect Dis. 2011;53 (Suppl 3);S110-28.

5. Centers for Disease Control and Prevention. Sexually Transmitted Diseases.Treatment Guidelines. 2010. Atlanta: CDC; 2010. [cited 2014 Jun 21]. Available from: [http://www. cdc.gov/std/treatment/2010/default.htm

6. Brasil. Ministério da Saúde. Secretaria de Vigilância em Saúde. Departamento de DST, Aids e Hepatites Virais. Bol Epidemiol Sífilis. 2012 [citado 2014 Jun 21];1. [Cited: Februari 19, 2014.] Disponível em http://boletim_sifilis_2012_pdf_26676pdf

7. Fu EX, Geraets RL Dodds EM, Echandl LV, Colombero D, McDonald HR, et al. Superficial retinal precipitates in patients with syphilitic retinitis. Retina. 2010;30(7):1135-43.

8. Yang P, Zhang N, Li F, Kilstra A. Ocular manifestations of syphilitic uveitis in chinese patients. Retina. 2012;32(9):1906-14.

9. Reddy S, Cunningham ET Jr, Spaide RF. Syphilitic retinitis with focal inflammatory accumulations. Ophthalmic Surg Lasers Imaging. 2006;37(5):429-31. 